\title{
Influence of the Mixing Ways of Reactants on ZnO Morphology
}

\author{
Lining Yang and Lan Xiang \\ Department of Chemical Engineering, Tsinghua University, Beijing 100084, China \\ Correspondence should be addressed to Lan Xiang; xianglan@mail.tsinghua.edu.cn
}

Received 29 December 2012; Accepted 27 February 2013

Academic Editor: Guo Gao

Copyright (C) 2013 L. Yang and L. Xiang. This is an open access article distributed under the Creative Commons Attribution License, which permits unrestricted use, distribution, and reproduction in any medium, provided the original work is properly cited.

\begin{abstract}
$\mathrm{ZnO}$ particles with various morphologies were synthesized by mixing $\mathrm{ZnSO}_{4}$ and $\mathrm{NaOH}$ solutions at $25^{\circ} \mathrm{C}$ followed by aging of the suspensions at $40-80^{\circ} \mathrm{C}$ for $2.0 \mathrm{~h}$, keeping the initial molar ratio of $\mathrm{Zn}^{2+}$ to $\mathrm{OH}^{-}$at $1: 4$. $\mathrm{ZnO}$ irregular plates were prepared by adding $\mathrm{NaOH}$ to $\mathrm{ZnSO}_{4}$ while $\varepsilon-\mathrm{Zn}(\mathrm{OH})_{2}$ rhombic particles were produced using the opposite mixing way. After aging of the slurries at $80^{\circ} \mathrm{C}$ for $2.0 \mathrm{~h}$, the $\mathrm{ZnO}$ plates were kept stable while the $\varepsilon-\mathrm{Zn}(\mathrm{OH})_{2}$ rhombic particles were converted to $\mathrm{ZnO}$ whiskers with a length of $1.0-4.0 \mu \mathrm{m}$ and a diameter of $0.03-0.3 \mu \mathrm{m}$. Thermodynamic analysis indicated that the formation of the $\mathrm{Zn}$-bearing precipitates $\left(\mathrm{ZnO}\right.$ or $\left.\varepsilon-\mathrm{Zn}(\mathrm{OH})_{2}\right)$ at room temperature was connected closely with the solution composition.
\end{abstract}

\section{Introduction}

The synthesis of $\mathrm{ZnO}$ with varying morphologies such as the multipods [1], the wires [2], the tubes [3], and the flowers [4] via the liquid-phase routes, including the chemical deposition [5], the microemulsion [6], the hydrothermal/solvothermal/sol-gel ways [7-9], the template-assisted method, and so forth [10], has attracted much attention in recent years owing to the moderate condition and the easy control of the properties of the $\mathrm{ZnO}$ products. Many former researchers have focused on the influence of surfactants on the morphology control of $\mathrm{ZnO}$. For example, Sun et al. [11] synthesized $\mathrm{ZnO}$ nanorods from $\mathrm{Zn}$ via the cetyltrimethylammoniumbromide- (CTAB-) assisted route and found that the presence of CTAB promoted the erosion of $\mathrm{Zn}$ and the hydrothermal formation of the $\mathrm{ZnO}$ nanorods at $180^{\circ} \mathrm{C}$. The needle- and flower-like $\mathrm{ZnO}$ nanocrystals were fabricated at $85^{\circ} \mathrm{C}$ by using $\mathrm{ZnCl}_{2}$ and $\mathrm{NaOH}$ as the reactants in the presence of $0.2 \mathrm{~mol} \cdot \mathrm{L}^{-1}$ sodium dodecyl sulfate (SDS) [12]. Some researchers have also studied the influence of the reactants, the solvent, and the $\mathrm{pH}$ on the morphology of $\mathrm{ZnO}$. For example, Gao et al. [13] fabricated the rotor-like $\mathrm{ZnO}$ at $100^{\circ} \mathrm{C}$ by treating the suspension containing the rod-like $\mathrm{ZnO}$ powders, which were produced from the $\mathrm{NH}_{3} \cdot \mathrm{H}_{2} \mathrm{O}$ and $\mathrm{ZnCl}_{2}$ and a saturated $\mathrm{Zn}(\mathrm{OH})_{4}{ }^{2-}$ solution obtained by dissolving $\mathrm{ZnO}$ in $5 \mathrm{~mol} \cdot \mathrm{L}^{-1} \mathrm{NaOH}$. Zheng et al. [14] prepared the porous octahedron- and rod-shaped $\mathrm{ZnO}$ architectures from $\mathrm{ZnC}_{2} \mathrm{O}_{4} \cdot 2 \mathrm{H}_{2} \mathrm{O}$, which was produced by the solvothermal treatment of the mixture of $\mathrm{ZnCl}_{2}, \mathrm{H}_{2} \mathrm{C}_{2} \mathrm{O}_{4} \cdot 2 \mathrm{H}_{2} \mathrm{O}$, $\mathrm{N}$-dimethylformamide (DNF), and methyl orange (MO) at $180^{\circ} \mathrm{C}$. Pal et al. [15] synthesized $\mathrm{ZnO}$ crystals with granular, flower-like and rod-like morphology by adjusting the $\mathrm{pH}$ of the suspension containing $\mathrm{Zn}\left(\mathrm{CH}_{3} \mathrm{COO}\right)_{2} \cdot 2 \mathrm{H}_{2} \mathrm{O}$ and ethylenediamine (EDA) at $80-100^{\circ} \mathrm{C}$.

Herein, a facile precipitation-aging method was developed in this paper to synthesize $\mathrm{ZnO}$ nanoparticles and $\mathrm{ZnO}$ whiskers simply by changing the mixing of $\mathrm{ZnSO}_{4}$ and $\mathrm{NaOH}$ solutions at room temperature followed by aging of the suspensions at $40-80^{\circ} \mathrm{C}$. The influence of the solution composition on the formation of the $\mathrm{Zn}$-bearing precursors and the morphology of the aging products were investigated.

\section{Experimental}

In a typical procedure, $20 \mathrm{~mL}$ of $8.0 \mathrm{~mol} \cdot \mathrm{L}^{-1} \mathrm{NaOH}$ was added drop-wise $\left(0.67 \mathrm{~mL} \cdot \mathrm{min}^{-1}\right)$ into $20 \mathrm{~mL}$ of $2.0 \mathrm{~mol} \cdot \mathrm{L}^{-1} \mathrm{ZnSO}_{4}$ at $25^{\circ} \mathrm{C}$, or using the opposite mixing way. The initial molar 


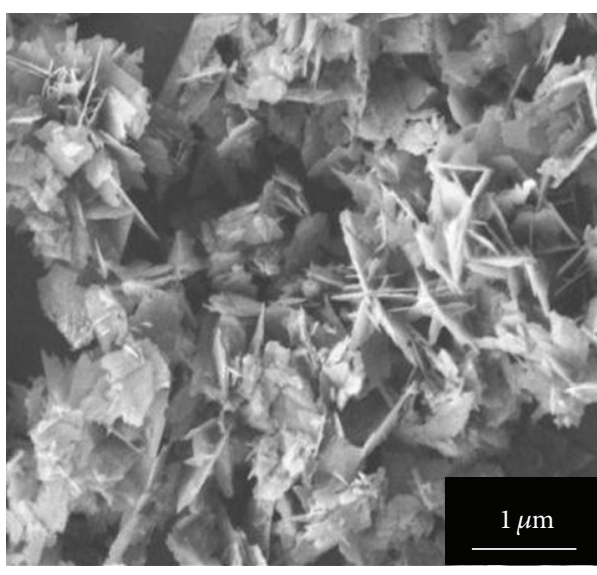

(a)

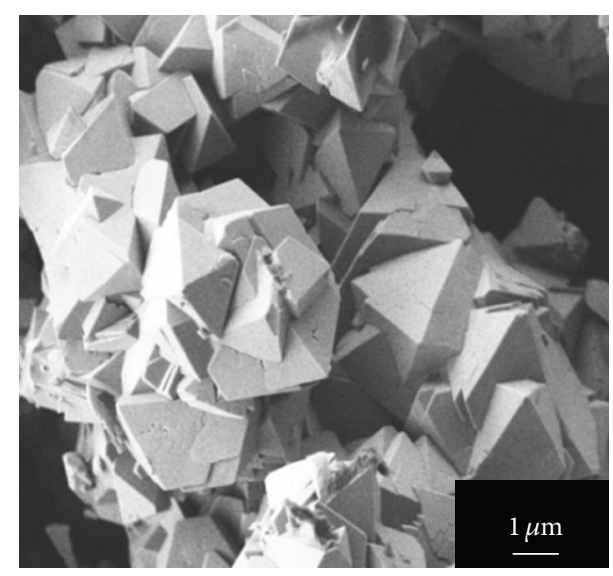

(b)

Figure 1: Morphology of the precipitates formed at $25^{\circ} \mathrm{C}$. Mixing of reactants: (a) adding $\mathrm{NaOH}$ to $\mathrm{ZnSO}_{4}$; (b) adding $\mathrm{ZnSO}_{4}$ to $\mathrm{NaOH}_{\text {. }}$

ratio of $\mathrm{Zn}^{2+}$ to $\mathrm{OH}^{-}$was $1: 4$. After being stirred $\left(150 \mathrm{~min}^{-1}\right)$ for $1.0 \mathrm{~h}$, the suspension was transferred to a Teflon-lined stainless autoclave with an inner volume of $60 \mathrm{~mL}$ and kept under isothermal condition at $80^{\circ} \mathrm{C}$ for $2.0 \mathrm{~h}$. The suspension was then cooled down to room temperature naturally; the precipitate was filtered, washed with deionized water for three times, and dried at $80^{\circ} \mathrm{C}$ for $4.0 \mathrm{~h}$.

The morphology and structure of the samples were characterized by the field-emission scanning electronic microscope (FE-SEM, JOEL 7401F, Japan) and the X-ray powder diffraction (XRD, D8 Advance, Bruker, Germany) using $\mathrm{CuK} \alpha$ radiation $(\lambda=1.5418 \AA)$, respectively. The solution $\mathrm{pH}$ was detected by the $\mathrm{pH}$ meter (FE20, METTLER-TOLEDO, Germany). The concentrations of soluble $\mathrm{Zn}^{2+}$ and $\mathrm{OH}^{-}$were analyzed by the ethylene diaminetetraacetic acid (EDTA) titration and the acid-base neutralization methods, respectively.

\section{Results and Discussion}

3.1. Influence of the Mixing Way on the Formation of the ZnBearing Precipitates. Figures 1 and 2 show the morphology and the XRD patterns of the $\mathrm{Zn}$-bearing precipitates formed at $25^{\circ} \mathrm{C}$. Wurtzite $\mathrm{ZnO}$ (space group $\mathrm{Pb}_{3} m c, a=b=3.250 \AA$, $c=5.207 \AA$ ) irregular plates with a diameter of $0.3-0.6 \mu \mathrm{m}$ were prepared if $\mathrm{NaOH}$ was added to $\mathrm{ZnSO}_{4}$, while $\varepsilon$ $\mathrm{Zn}(\mathrm{OH})_{2}$ (space group P212121, $a=8.490 \AA, b=5.162 \AA$, $c=4.917 \AA$ ) agglomerated octahedral particles with a diameter of $1.0-3.0 \mu \mathrm{m}$ were produced if $\mathrm{ZnSO}_{4}$ was added to $\mathrm{NaOH}$.

Figure 3 shows the variation of the total $\mathrm{Zn}^{2+}$ concentration $\left([\mathrm{Zn}]_{\mathrm{T}}\right)$ and the solution $\mathrm{pH}$ with the reaction time at $25^{\circ} \mathrm{C}$. In the case of adding $\mathrm{NaOH}$ to $\mathrm{ZnSO}_{4}$ (Figure 3(a)), with the increase of the reaction time from 0 to $60 \mathrm{~min}$, $[\mathrm{Zn}]_{\mathrm{T}}$ decreased from $2.0 \mathrm{~mol} \cdot \mathrm{L}^{-1}$ to $0.08 \mathrm{~mol} \cdot \mathrm{L}^{-1}$ and the solution $\mathrm{pH}$ increased from 3.8 to 12.6; in the case of adding $\mathrm{ZnSO}_{4}$ to $\mathrm{NaOH}$ (Figure 3(b)), the increase of the reaction time from 0 to $60 \mathrm{~min}$ led to the decrease of $\left[\mathrm{OH}^{-}\right]$from $8.0 \mathrm{~mol} \cdot \mathrm{L}^{-1}$ to $1.4 \mathrm{~mol} \cdot \mathrm{L}^{-1}$, while the $[\mathrm{Zn}]_{\mathrm{T}}$ increased from
0 to $0.36 \mathrm{~mol} \cdot \mathrm{L}^{-1}$ at the initial $30 \mathrm{~min}$ and then decreased gradually to $0.19 \mathrm{~mol} \cdot \mathrm{L}^{-1}$ as the reaction time increased from $30 \mathrm{~min}$ to $60 \mathrm{~min}$.

Table 1 shows the possible equilibrium reactions existed in the $\mathrm{ZnSO}_{4}-\mathrm{NaOH}-\mathrm{H}_{2} \mathrm{O}$ system. The equilibrium constants in Table 1 were calculated from the HSC 7.1 software.

Based on the simultaneous equilibrium principle, the equilibrium concentrations of the soluble ions in varying time can be calculated from the knowing concentrations of total soluble $\mathrm{Zn}^{2+}, \mathrm{OH}^{-}, \mathrm{Na}^{+}$, and $\mathrm{SO}_{4}{ }^{2-}$. To simplify the calculation process, the activity of each species was replaced by concentration due to the shortage of the basic data. Based on these equations above and the experimental data in Figure 3, the concentrations of the soluble $\mathrm{Zn}$-bearing species at different reaction time were calculated and the results are shown in Figure 4.

In the case of adding $\mathrm{NaOH}$ to $\mathrm{ZnSO}_{4}$ (Figure 4(a)), $\mathrm{Zn}(\mathrm{OH})_{2(\mathrm{aq})}$ was the predominant species and the increase of the reaction time from $10 \mathrm{~min}$ to $60 \mathrm{~min}$ led to the decrease of $\left[\mathrm{Zn}^{2+}\right]$ and $\left[\mathrm{ZnOH}^{+}\right]$and the increase of $\left[\mathrm{Zn}(\mathrm{OH})_{3}{ }^{-}\right]$, $\left[\mathrm{HZnO}_{2}{ }^{-}\right],\left[\mathrm{Zn}(\mathrm{OH})_{4}{ }^{2-}\right]$, and $\left[\mathrm{ZnO}_{2}{ }^{2-}\right]$. In the case of adding $\mathrm{ZnSO}_{4}$ to $\mathrm{NaOH}$ (Figure 4(b)), all of the $\mathrm{Zn}$-bearing species were kept quite stable within $60 \mathrm{~min}$, and the order of concentrations for these species was $\left[\mathrm{Zn}(\mathrm{OH})_{4}{ }^{2-}\right] \approx\left[\mathrm{ZnO}_{2}{ }^{-}\right]>$ $\left[\mathrm{Zn}(\mathrm{OH})_{3}{ }^{-}\right] \approx\left[\mathrm{HZnO}_{2}{ }^{-}\right]>\left[\mathrm{Zn}(\mathrm{OH})_{2(\mathrm{aq})}\right]>\left[\mathrm{ZnOH}^{+}\right]>$ $\left[\mathrm{Zn}^{2+}\right]$. The difference in the solution composition may be one of the major reasons for the formation of different precipitates $\left(\mathrm{ZnO}\right.$ and $\left.\varepsilon-\mathrm{Zn}(\mathrm{OH})_{2}\right)$.

3.2. Aging of the $\mathrm{ZnO}$ and $\varepsilon$ - $\mathrm{Zn}(\mathrm{OH})_{2}$ Precipitates. The morphology and the XRD patterns of the aging products formed from $\mathrm{ZnO}$ and $\varepsilon$ - $\mathrm{Zn}(\mathrm{OH})_{2}$ precursors were shown in Figures 5 and 6 , respectively. Irregular $\mathrm{ZnO}$ plates with a similar morphology using the $\mathrm{ZnO}$ precursor were formed after aging treatment at $40-80^{\circ} \mathrm{C}$, indicating that $\mathrm{ZnO}$ precursor was quite stable under the experimental conditions. In the case of the $\varepsilon-\mathrm{Zn}(\mathrm{OH})_{2}$ precursor, the precursor was stable up to $40^{\circ} \mathrm{C}$, but changed 


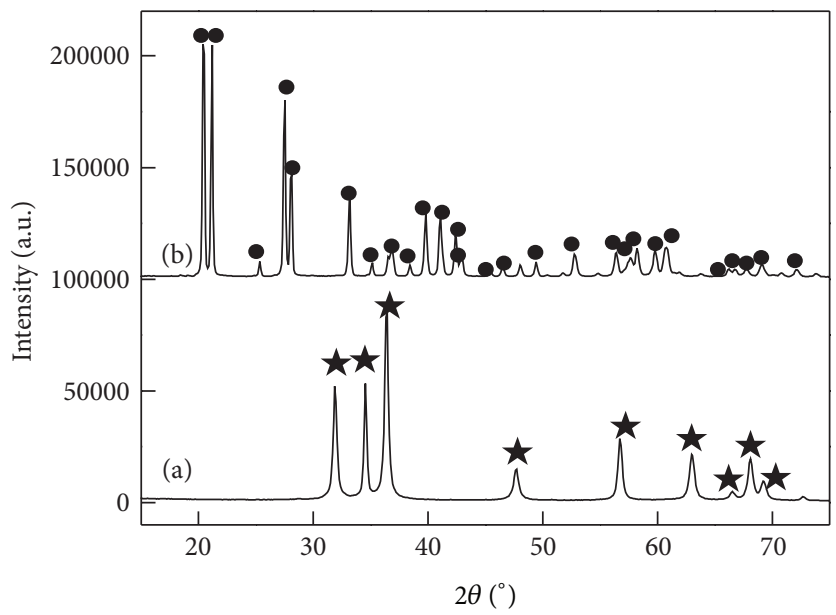

Figure 2: XRD patterns of the precipitates formed at $25^{\circ} \mathrm{C}$. Mixing of reactants: (a) adding $\mathrm{NaOH}$ to $\mathrm{ZnSO}_{4}$; (b) adding $\mathrm{ZnSO}_{4}$ to $\mathrm{NaOH}_{\text {. }} \star$ : $\mathrm{ZnO}, \bullet: \varepsilon-\mathrm{Zn}(\mathrm{OH})_{2}$.

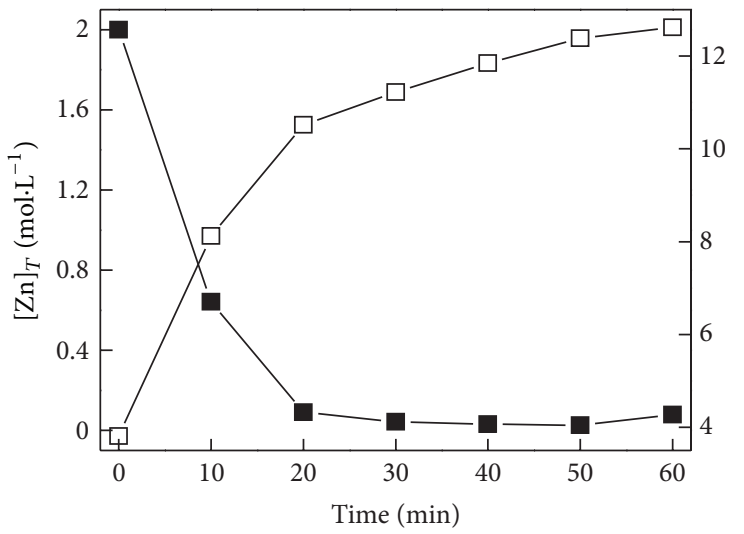

(a)

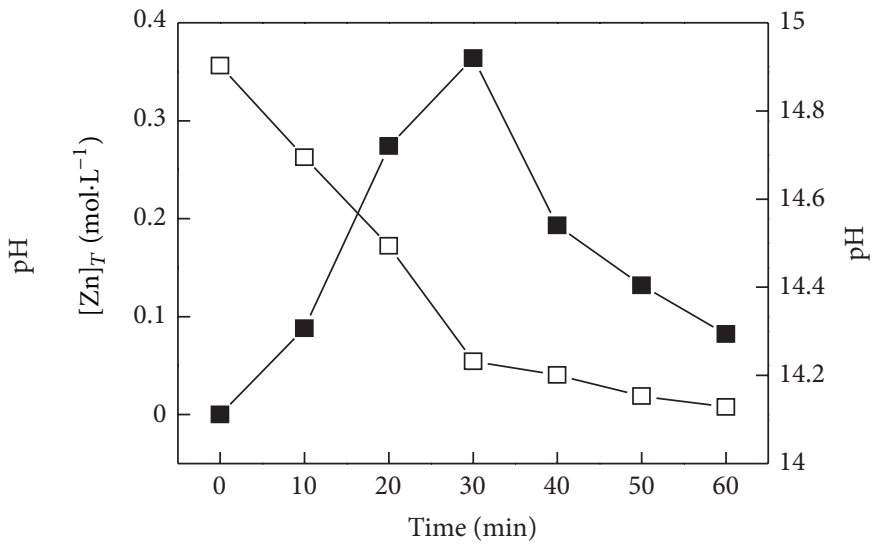

(b)

FIGURE 3: Influence of the mixing ways of the reactants on $[\mathrm{Zn}]_{\mathrm{T}}$ and $\mathrm{pH}$. Mixing of reactants: (a) adding $\mathrm{NaOH}_{\text {to }} \mathrm{ZnSO}_{4}$; (b) adding $\mathrm{ZnSO}_{4}$ to $\mathrm{NaOH} ; \boldsymbol{\mathbf { a }}:[\mathrm{Zn}]_{\mathrm{T}}, \square: \mathrm{pH}$.

to $\mathrm{ZnO}$ rods with a length of $0.1-0.4 \mu \mathrm{m}$ and a diameter of $40-100 \mathrm{~nm}$ and $\mathrm{ZnO}$ whiskers with a length of $1.0-14.0 \mu \mathrm{m}$ and a diameter of $0.03-0.3 \mu \mathrm{m}$ after aging treatment at $60^{\circ} \mathrm{C}$ and $80^{\circ} \mathrm{C}$, respectively. The different aging behaviors of $\mathrm{ZnO}$ and $\varepsilon-\mathrm{Zn}(\mathrm{OH})_{2}$ precursors may be connected with their different dissolution abilities in $\mathrm{NaOH}$ solution.

Figure 7 shows the dissolution of $\mathrm{ZnO}$ and $\varepsilon-\mathrm{Zn}(\mathrm{OH})_{2}$ after mixing excessive amount $(3.500 \mathrm{~g})$ of $\mathrm{ZnO}$ or $\varepsilon$ $\mathrm{Zn}(\mathrm{OH})_{2}$ with $25 \mathrm{~mL}$ of $8.0 \mathrm{~mol} \cdot \mathrm{L}^{-1} \mathrm{NaOH}$ at $25-80^{\circ} \mathrm{C}$ for $2.0 \mathrm{~h}$. The increase of temperature from $25^{\circ} \mathrm{C}$ to $80^{\circ} \mathrm{C}$ favored the dissolution of $\mathrm{ZnO}$ and $\varepsilon-\mathrm{Zn}(\mathrm{OH})_{2}$ in $\mathrm{NaOH}$ solution. Compared with $\mathrm{ZnO}, \varepsilon-\mathrm{Zn}(\mathrm{OH})_{2}$ was more soluble, which favored the formation of $\mathrm{ZnO}$ whiskers via the dissolutionprecipitation route [16]:

$$
\varepsilon-\mathrm{Zn}(\mathrm{OH})_{2} \stackrel{\text { dissolution }}{\longrightarrow} \mathrm{Zn}^{2+}+2 \mathrm{OH}^{-}
$$

TABLE 1: Thermodynamic equilibrium reactions in $\mathrm{ZnSO}_{4}-\mathrm{NaOH}-$ $\mathrm{H}_{2} \mathrm{O}$ system $(298 \mathrm{~K})$.

\begin{tabular}{lcl}
\hline Reactions & Constant \\
\hline $\mathrm{H}_{2} \mathrm{O}=\mathrm{H}^{+}+\mathrm{OH}^{-}$ & $1.02 \times 10^{-14}$ \\
$\mathrm{ZnSO}_{4}=\mathrm{Zn}^{2+}+\mathrm{SO}_{4}{ }^{2-}$ & $2.23 \times 10^{3}$ \\
$\mathrm{HSO}_{4}{ }^{-}=\mathrm{SO}_{4}{ }^{2-}+\mathrm{H}^{+}$ & $1.04 \times 10^{-2}$ \\
$\mathrm{H}_{2} \mathrm{SO}_{4}=\mathrm{HSO}_{4}^{-}+\mathrm{H}^{+}$ & $3.46 \times 10^{9}$ \\
$\mathrm{NaOH}^{+} \mathrm{Na}^{+}+\mathrm{OH}^{-}$ & $8.45 \times 10^{6}$ \\
$\mathrm{Na}_{2} \mathrm{SO}_{4}=2 \mathrm{Na}^{+}+\mathrm{SO}_{4}{ }^{2-}$ & $4.73 \times 10^{-1}$ \\
$\mathrm{Zn}^{2+}+2 \mathrm{OH}^{-}=\mathrm{HZnO}_{2}{ }^{-}+\mathrm{H}^{+}$ & 1.73 \\
$\mathrm{Zn}^{2+}+2 \mathrm{OH}^{-}=\mathrm{ZnO}_{2}{ }^{2-}+2 \mathrm{H}^{+}$ & $2.90 \times 10^{-13}$ \\
$\mathrm{Zn}^{2+}+\mathrm{OH}^{-}=\mathrm{ZnOH}$ & \\
$\mathrm{Zn}^{2+}+2 \mathrm{OH}^{-}=\mathrm{Zn}(\mathrm{OH})_{2(\mathrm{aq})}$ & $1.44 \times 10^{6}$ \\
$\mathrm{Zn}^{2+}+3 \mathrm{OH}^{-}=\mathrm{Zn}(\mathrm{OH})_{3}{ }^{2}$ & $1.16 \times 10^{13}$ \\
$\mathrm{Zn}^{2+}+4 \mathrm{OH}^{-}=\mathrm{Zn}(\mathrm{OH})_{4}{ }^{2-}$ & $2.50 \times 10^{14}$
\end{tabular}

$$
\stackrel{\text { precipitation }}{\longrightarrow} \mathrm{ZnO}_{\mathrm{w}}+\mathrm{H}_{2} \mathrm{O}
$$




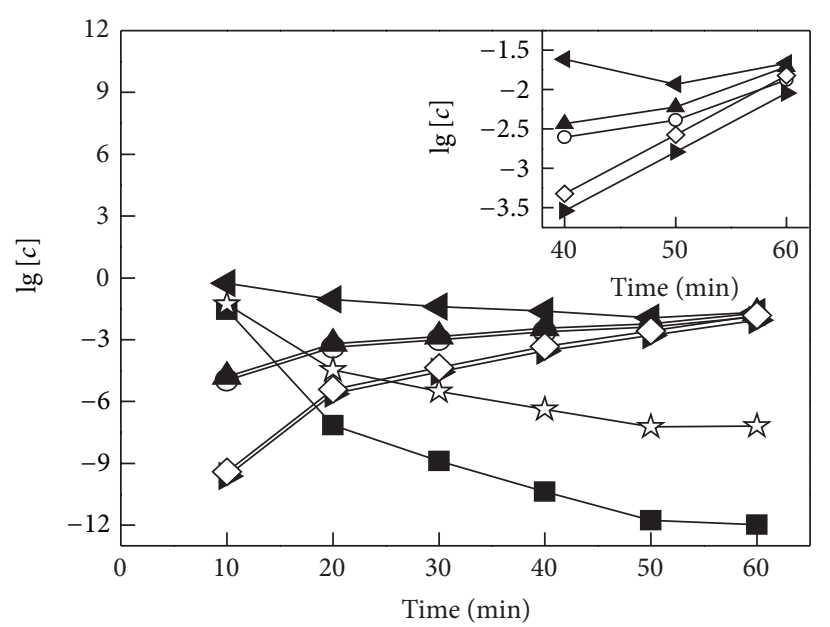

(a)

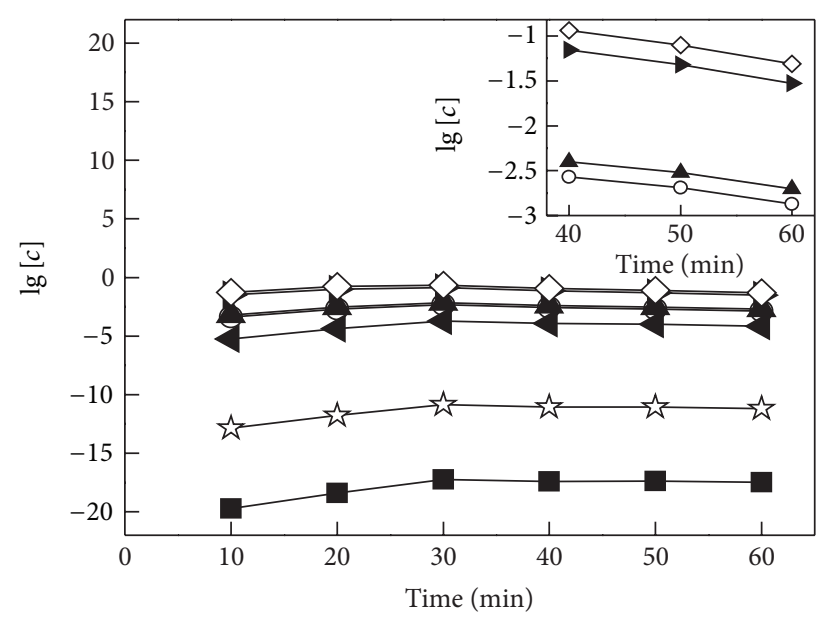

(b)

Figure 4: Variation of the soluble $\mathrm{Zn}$-bearing species with time. Mixing of reactants: (a) adding $\mathrm{NaOH}_{\text {to }} \mathrm{ZnSO}_{4}$; (b) adding $\mathrm{ZnSO}_{4}$ to $\mathrm{NaOH}_{\text {. }}$

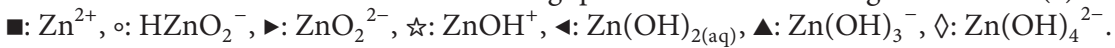

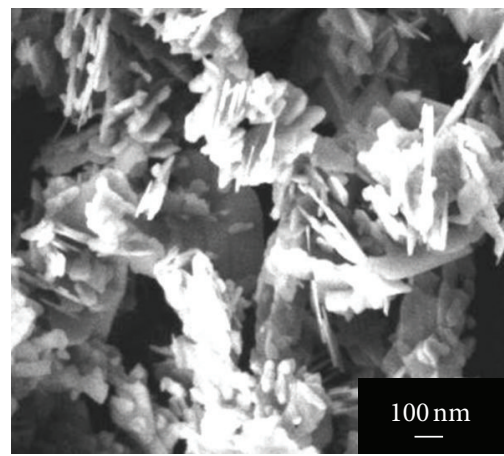

(a)

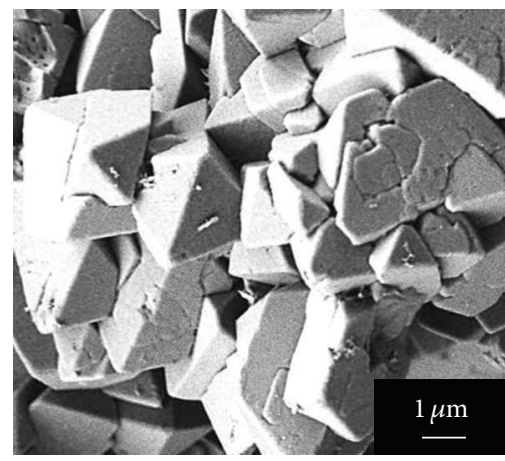

(d)

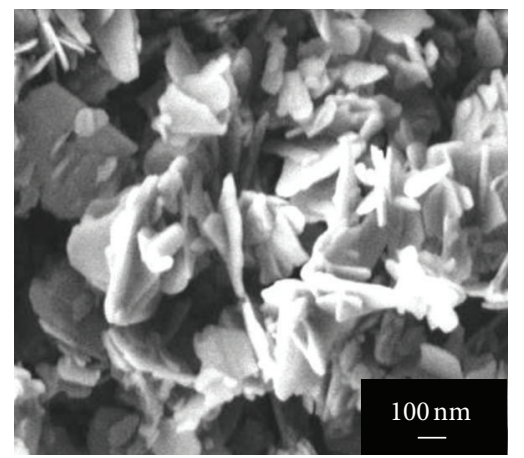

(b)

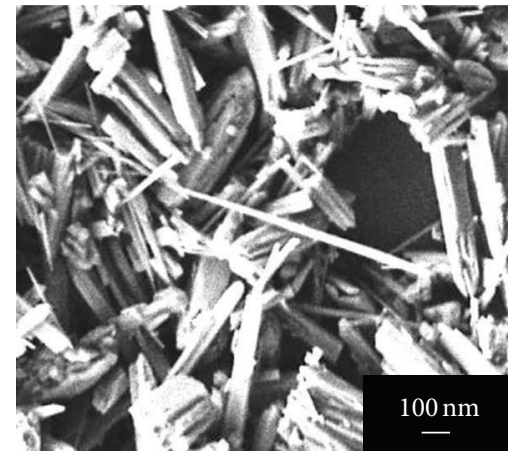

(e)

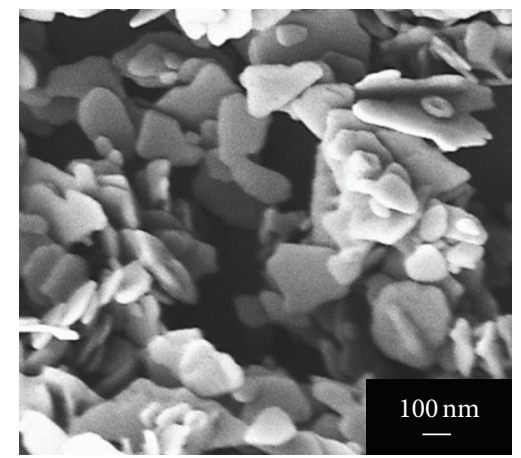

(c)

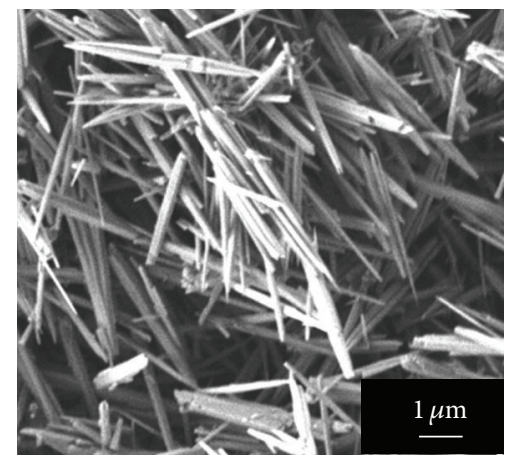

(f)

FIGURE 5: Morphology of the aging products formed from $\mathrm{ZnO}((\mathrm{a})-(\mathrm{c}))$ and $\varepsilon-\mathrm{Zn}(\mathrm{OH})_{2}((\mathrm{~d})-(\mathrm{f}))$. Aging temperature $\left({ }^{\circ} \mathrm{C}\right):(\mathrm{a}),(\mathrm{d}): 40$; (b), (e): $60 ;(\mathrm{c}),(\mathrm{f}): 80$.

\section{Conclusions}

$\mathrm{ZnO}$ particles and whiskers were synthesized by changing the mixing ways of $\mathrm{ZnSO}_{4}$ and $\mathrm{NaOH}$ at room temperature followed by aging of the suspensions at $40-80^{\circ} \mathrm{C}$ for $2.0 \mathrm{~h}$. Irregular $\mathrm{ZnO}$ plates were formed by adding $\mathrm{NaOH}$ to $\mathrm{ZnSO}_{4}$ while $\varepsilon-\mathrm{Zn}(\mathrm{OH})_{2}$ rhombic particles were produced using the opposite mixing way. Thermodynamic analysis indicated that the formation of $\mathrm{ZnO}$ and $\varepsilon-\mathrm{Zn}(\mathrm{OH})_{2}$ in different mixing ways of $\mathrm{ZnSO}_{4}$ and $\mathrm{NaOH}$ should be attributed to the different solution compositions. The aging of the slurries containing $\varepsilon-\mathrm{Zn}(\mathrm{OH})_{2}$ and $\mathrm{NaOH}$ at $80^{\circ} \mathrm{C}$ for $2.0 \mathrm{~h}$ led to the formation of $\mathrm{ZnO}$ whiskers with a length of 1.0-4.0 $\mu \mathrm{m}$ and a diameter of $0.03-0.3 \mu \mathrm{m}$ owing to the easy dissolving of 

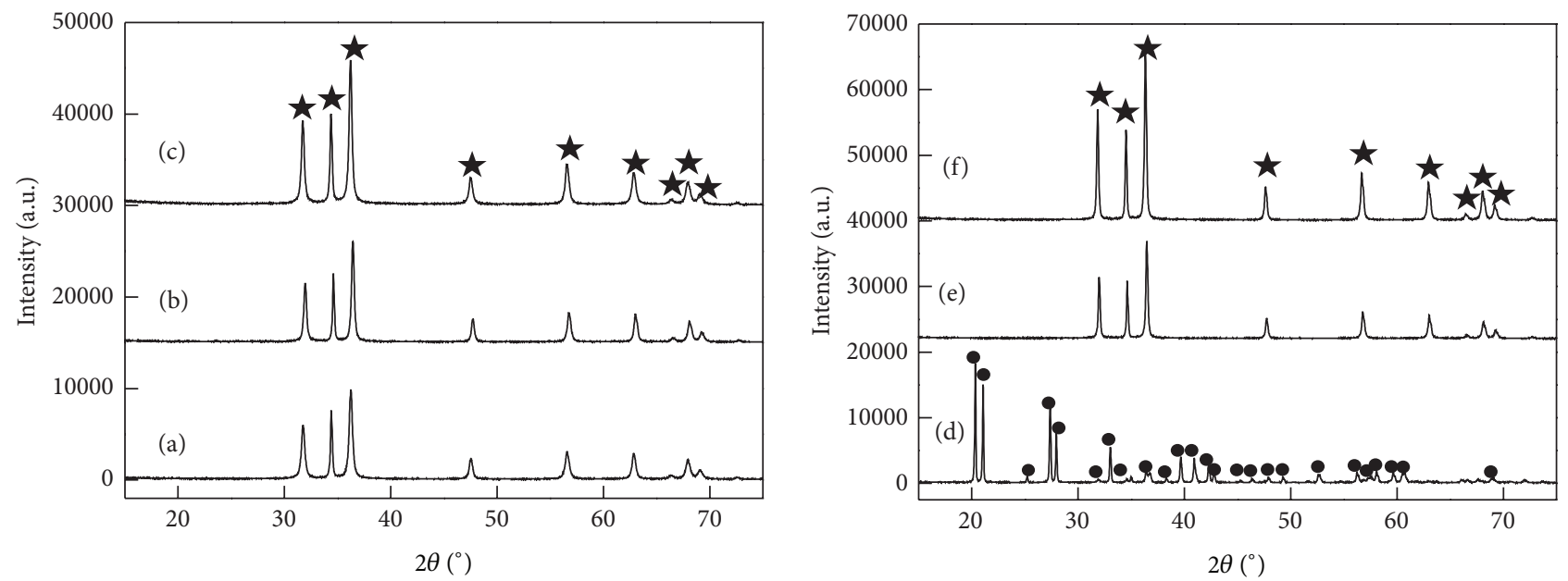

FIGURE 6: XRD patterns of the aging products formed from $\mathrm{ZnO}((\mathrm{a})-(\mathrm{c}))$ and $\varepsilon$ - $\mathrm{Zn}(\mathrm{OH})_{2}((\mathrm{~d})-(\mathrm{e}))$. Aging temperature $\left({ }^{\circ} \mathrm{C}\right)$ : (a), (d): 40; (b), (e): $60 ;(\mathrm{c}),(\mathrm{f}): 80 ; \star: \mathrm{ZnO}, \bullet: \varepsilon-\mathrm{Zn}(\mathrm{OH})_{2}$.

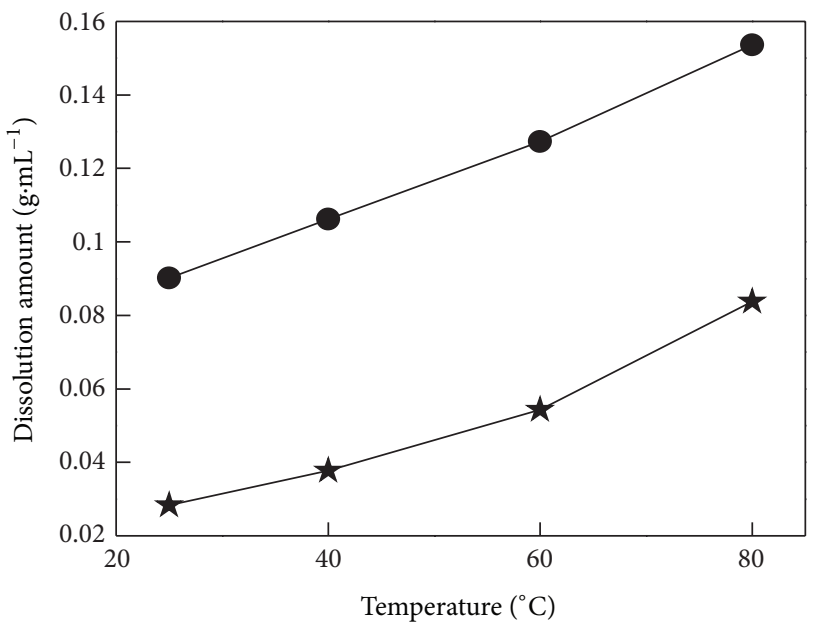

Figure 7: Dissolution curves of $\varepsilon-\mathrm{Zn}(\mathrm{OH})_{2}$ and $\mathrm{ZnO}$ in $\mathrm{NaOH}$ solution; $\star: \mathrm{ZnO}, \bullet: \varepsilon-\mathrm{Zn}(\mathrm{OH})_{2}$.

$\varepsilon-\mathrm{Zn}(\mathrm{OH})_{2}$ in $\mathrm{NaOH}$ solution, while the $\mathrm{ZnO}$ plates were quite stable throughout the aging treatment.

\section{Acknowledgments}

This work was supported by the National Natural Science Foundation of China (no. 51174125 and no. 51234003) and the National Hi-tech Research and Development Program of China (863 Program, 2012AA061602).

\section{References}

[1] J. Wang and L. Gao, "Synthesis of uniform rod-like, multi-podlike $\mathrm{ZnO}$ whiskers and their photoluminescence properties," Journal of Crystal Growth, vol. 262, no. 1-4, pp. 290-294, 2004.

[2] J. Zhang, L. Sun, H. Pan, C. Liaoa, and C. Yan, "ZnO nanowires fabricated by a convenient route," New Journal of Chemistry, vol. 26, no. 1, pp. 33-34, 2002.
[3] B. I. Seo, U. A. Shaislamov, M. H. Ha, S. W. Kim, H. K. Kim, and B. Yang, "ZnO nanotubes by template wetting process," Physica E, vol. 37, no. 1-2, pp. 241-244, 2007.

[4] R. Wahab, S. G. Ansari, Y. S. Kim et al., "Low temperature solution synthesis and characterization of $\mathrm{ZnO}$ nano-flowers," Materials Research Bulletin, vol. 42, no. 9, pp. 1640-1648, 2007.

[5] J. Lu and K. M. Ng, "Efficient, one-step mechanochemical process for the synthesis of $\mathrm{ZnO}$ nanoparticles," Industrial \& Engineering Chemistry Research, vol. 47, pp. 1095-1101, 2008.

[6] X. Li, G. He, G. Xiao, H. Liu, and M. Wang, "Synthesis and morphology control of $\mathrm{ZnO}$ nanostructures in microemulsions," Journal of Colloid and Interface Science, vol. 333, no. 2, pp. 465473, 2009.

[7] B. Cheng and E. T. Samulski, "Hydrothermal synthesis of onedimensional $\mathrm{ZnO}$ nanostructures with different aspect ratios," Chemical Communications, vol. 10, no. 8, pp. 986-987, 2004.

[8] A. Pan, R. Yu, S. Xie, Z. Zhang, C. Jin, and B. Zou, "ZnO flowers made up of thin nanosheets and their optical properties," Journal of Crystal Growth, vol. 282, no. 1-2, pp. 165-172, 2005.

[9] X. Yang, C. Shao, H. Guan, X. Li, and J. Gong, "Preparation and characterization of $\mathrm{ZnO}$ nanofibers by using electrospun PVA/zinc acetate composite fiber as precursor," Inorganic Chemistry Communications, vol. 7, no. 2, pp. 176-178, 2004.

[10] X. Yan, Z. Li, R. Chen, and W. Gao, "Template growth of ZnO nanorods and microrods with controllable densities," Crystal Growth and Design, vol. 8, no. 7, pp. 2406-2410, 2008.

[11] X. M. Sun, X. Chen, Z. X. Deng, and Y. D. Li, "A CTAB-assisted hydrothermal orientation growth of $\mathrm{ZnO}$ nanorods," Materials Chemistry and Physics, vol. 78, no. 1, pp. 99-104, 2003.

[12] J. Xie, P. Li, Y. Li, Y. Wang, and Y. Wei, "Morphology control of $\mathrm{ZnO}$ particles via aqueous solution route at low temperature," Materials Chemistry and Physics, vol. 114, no. 2-3, pp. 943-947, 2009.

[13] X. P. Gao, Z. F. Zheng, H. Y. Zhu et al., "Rotor-like ZnO by epitaxial growth under hydrothermal conditions," Chemical Communications, no. 12, pp. 1428-1429, 2004.

[14] J. Zheng, Z. Y. Jiang, Q. Kuang, Z. X. Xie, R. B. Huang, and L. S. Zheng, "Shape-controlled fabrication of porous $\mathrm{ZnO}$ 
architectures and their photocatalytic properties," Journal of Solid State Chemistry, vol. 182, no. 1, pp. 115-121, 2009.

[15] U. Pal, J. G. Serrano, P. Santiago, G. Xiong, K. B. Ucer, and R. T. Williams, "Synthesis and optical properties of $\mathrm{ZnO}$ nanostructures with different morphologies," Optical Materials, vol. 29, no. 1, pp. 65-69, 2006.

[16] R. A. McBride, J. M. Kelly, and D. E. McCormack, "Growth of well-defined $\mathrm{ZnO}$ microparticles by hydroxide ion hydrolysis of zinc salts," Journal of Materials Chemistry, vol. 13, no. 5, pp. 1196-1201, 2003. 

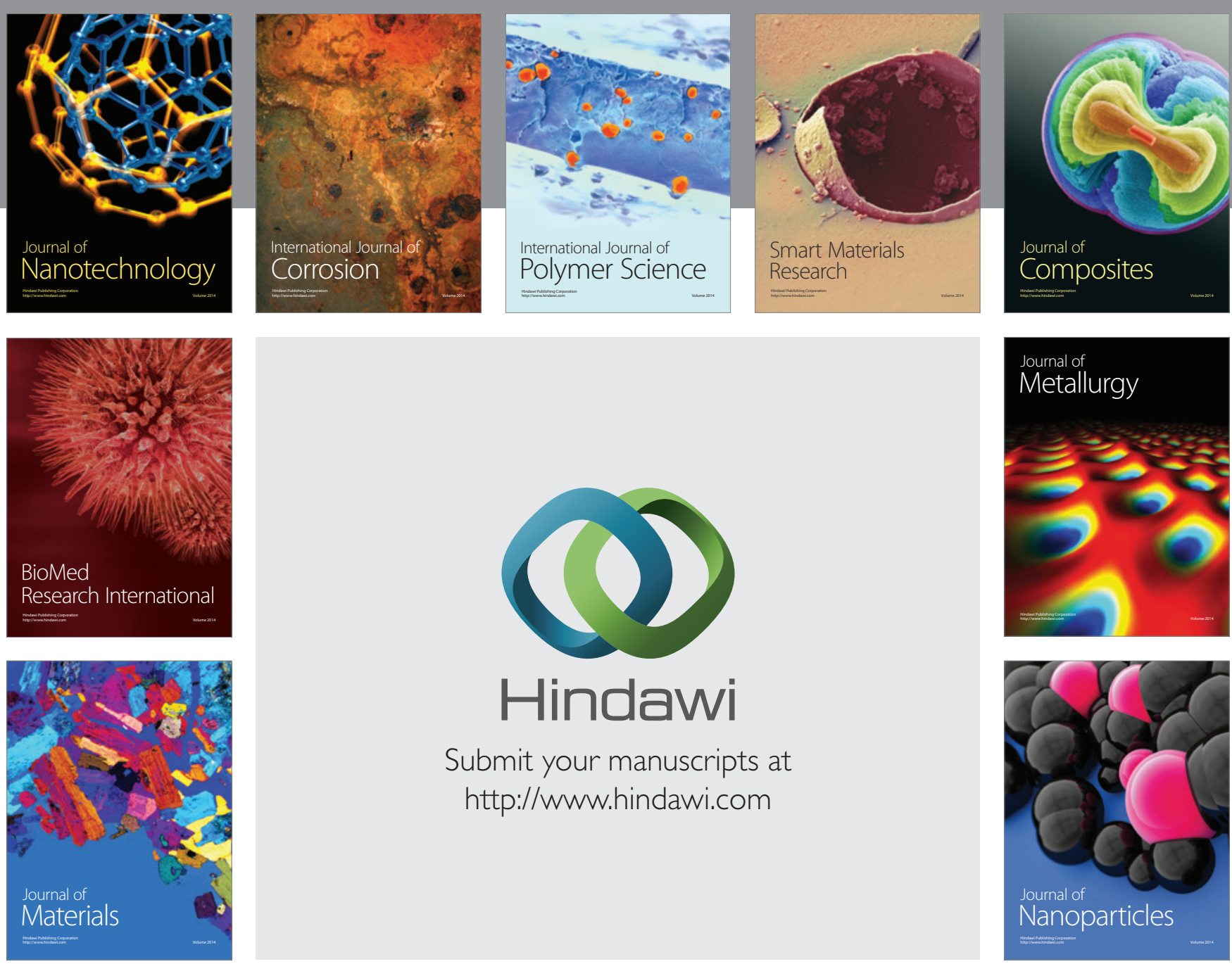

Submit your manuscripts at http://www.hindawi.com
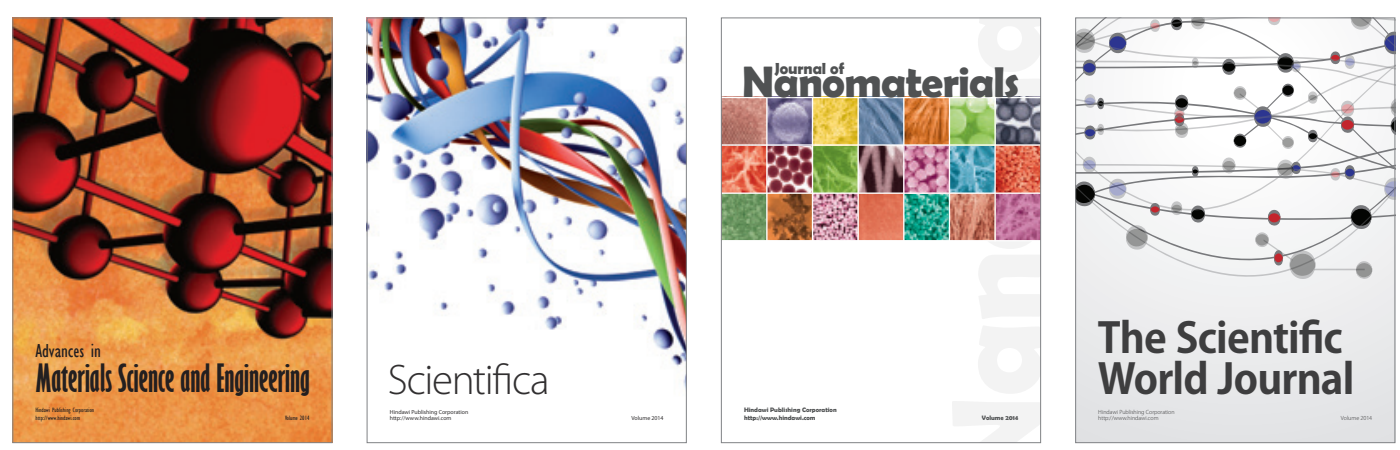

\section{The Scientific World Journal}
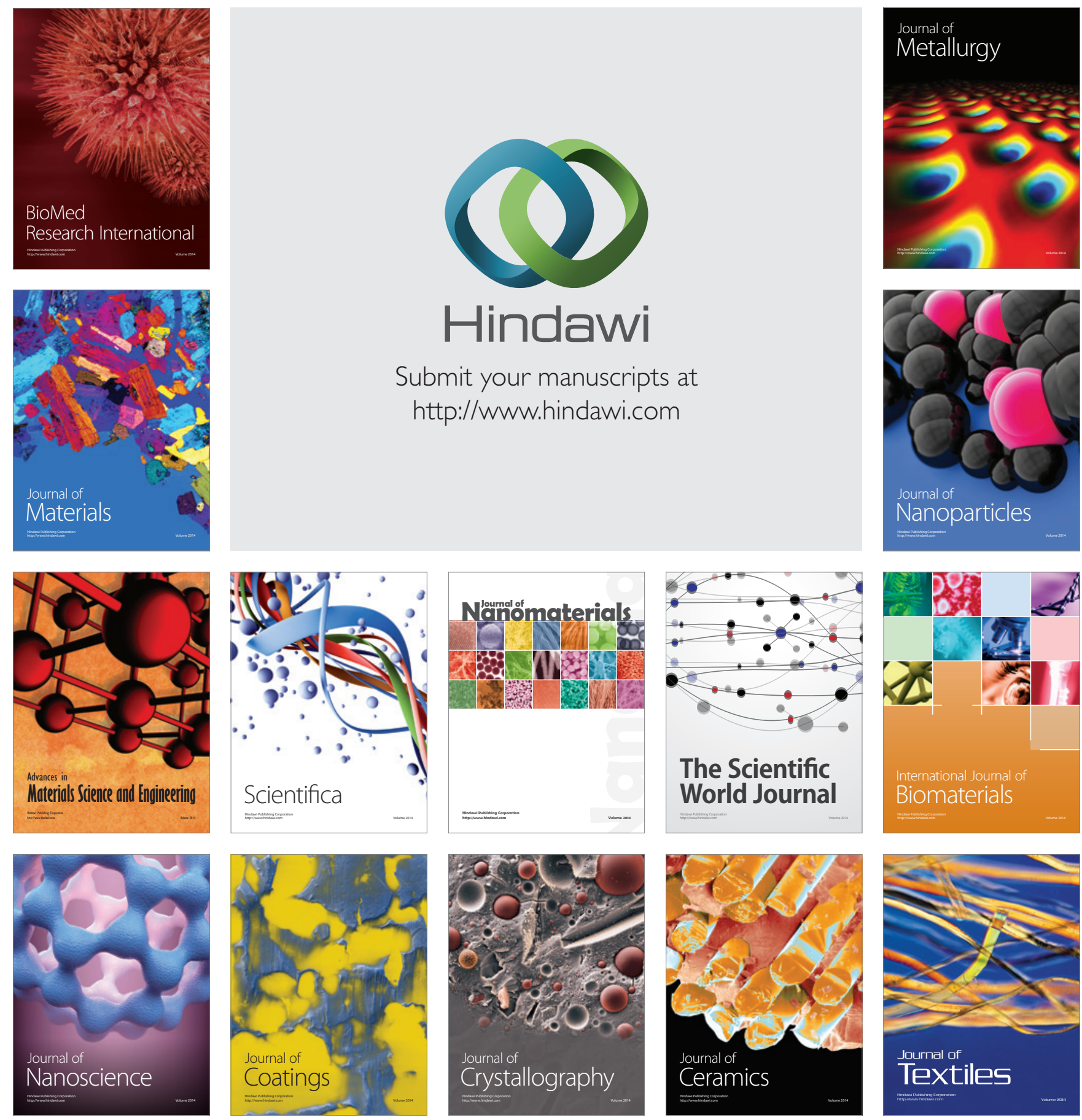